\title{
多摩丘陵源流域における流出機構
}

\section{田中 正*・安原正也**・丸井敦尚**}

\begin{abstract}
多摩丘陵の一角に設定した流域面積 2.2haの小試験流域において, 野外観測に基づいて降雨流出時におけ る流出成分の主体を明らかにするとともに, その流出機構について考察を行なった. その結果, 以下の結論 が得られた. (1)降雨流出時における流出成分の主体は地下水流出成分である. 総流出量の約 $90 \%$ は地下水流 出成分に起因しており, 表面流出成分は総流出量のわずか $10 \%$ 程度を占めるにすぎない. (2)降雨に対する応 答の早、多量の地下水流出は, ダルシー則に基づく流れでは説明することができない. 降雨流出時において は, ダルシー流よりはるかに速い卓越流が地層中に存在している. (3)この卓越流は, 地層中に形成された パイプの中を流れるパイプ流であり, 良好な排水機能としてのパイプ流は, 丘陵地源流域における流出機構 を考える上で, 重要な役割を果たしている. (4)パイプ流の特徵として, pulsating flow 現象が認められる.
\end{abstract}

\section{Iはじめに}

わが国の森林流域における流出機構, あるいは水 流発生機構を明らかにすることは, 流域の水循環機 構や物質循環機構を解明する上で重要である.この 研究課題は古くから水文学の中心課題と考えられて きだ(榧根，1980，p. 245)が，わが国では理想的な 試験流域を確保することの困難さと，現場における 水文観測のむつかしさのため, この種の解析に耐え うる充分な資料の蓄積はなく, 従来までの解析の多 くはブラック・ボックス的な性格を有していた。

しかるに，最近における野外観測に基づいた各国 での精力的な研究の進展により, 湿潤森林流域での 流出現象の実態は，かなりの程度明らかにされつつ ある(Kirkby, 1978).これまでの研究結果によれば, 湿潤森林流域においては，ホートンタイプの地表流 はほとんど発生せず, 降雨流出時の水流発生に大き く寄与する流れは, saturated overland flow (Dunne and Black, 1970), subsurface stormflow (Whipkey, 1965, 1969 ; Weyman, 1970, 1973) および groundwater flow (Fritz et al., 1976 ; Sklash and Farvolden, 1979) の三つに大別することができる. そして, 降雨流出時におけるハイドログラフの形成 に, いずれの流れが最も大きく貢献するかは, 対象 *筑波大学・地球科学系 $* *$ 筑波大学・院
地域の地形・地質・気候・植生・土䁃特性・土地利 用等によって異なるとされている(Freeze, 1974).

一方，わが国における森林流域の流出機構を，野 外観測に基づいて実態論的に論じた研究は少なく， 塚本(1962)の研究があげられるにすぎない，田中ほ か(1982)は, 丘陵地源流域における流出機構を解明 するにあたり, 地表水と地中水を一体とした一つの システムとしてとらえる必要があるとの観点から， 多摩丘陵の一角に設定した試験流域を例に, 流出現 象と地中水の挙動との関連を明らかにした.しかし， 流出機構そのものについては言及しておらず，今後 の研究課題として残されていた。

本研究は, 田中ほか (1982)に続く一連の研究の一 つであり, その後の観測データに基づいて, 多摩丘 陵源流域に打ける降雨流出時の水流発生に, 最も大 きく関与している流れの主体を特定するとともに, その流出機構について考察を行なったものである.

\section{II 試験流域および観測施設の概要}

\section{1）試験流域の概要}

試験流域は東京都八王子市堀の内, 東京農工大学 波丘地利用実験実習施設内に設置されている（第 1 図). 流域は, 多摩丘陵の北縁に位置し, 多摩川の 支流大栗川の一源流部を構成している. 流域の標高 は144 183m, 流域面積は $0.022 \mathrm{~km}^{2}$ である. 流 


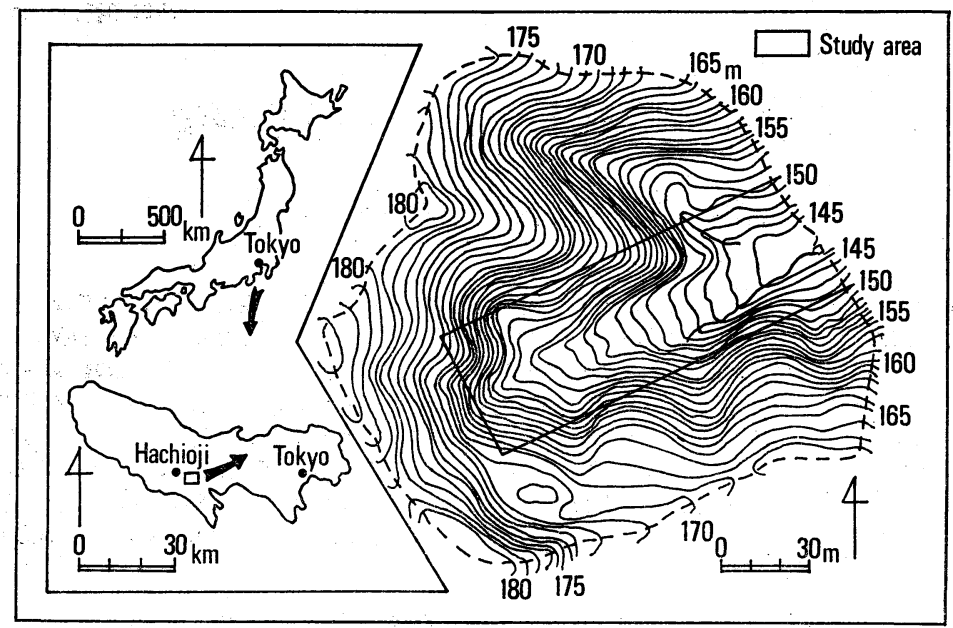

第1困試験流域位置図

Fig. 1 Location of the study area

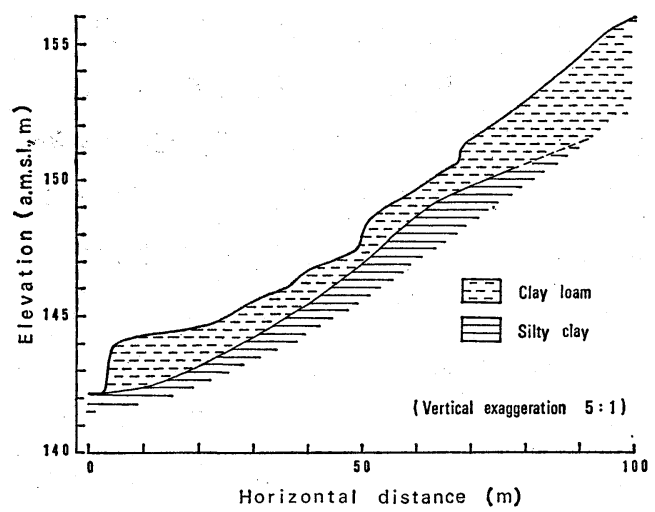

第 2 図“谷底面の縦断プロファイルと地質断面

Fig. 2 Longitudinal profile and geological section of the valley floor

域谷底面の地形勾配は約 $12 \%$ ，山腹斜面のそれは約 $50 \%$ あるる。

試験流域付近の地質は，下位から上位に平山砂層， 三沢泥岩層, 連光寺互層, 御殿峠碟層および関東口 一公層が分布する(寿円・原田, 1961)が, 本流域の 主たる構成層は, 連光寺互層 (標高140 160m), 御 殿峠碟層(標高 $160 \mathrm{~m}$ 以上) お゙よび関東ローム層であ る.

谷底の表層約 $2 \mathrm{~m}$ は, シルトおよび粘土分を主体 とした埴堙土 (clay loam)およびシルト質埴土 (silty clay) から構成されている(Tanaka et al., 1981). これら谷底の堆積物は，粒度組成の上から判断する と, オリジナルな関東ローム層とは異なり, いわゆ る二次堆積物であるものと思われる. 観測井掘削時 のボーリング資料に基づき, 谷底面における表層堆 積物の縦断プロファイルを示したのが第 2 図である.

植生はクヌギ, コナラを主体とする落葉広葉樹が 流域のほぼ全域を占めている. 斜面では背丈 $2 \sim 3 \mathrm{~m}$ の竹が密生し, 谷底では春から夏にかけてシダ類が 繁茂する，人工の構造物はなく，まったくの自然流 域である.

\section{2) 観測施設の概要}

観測施設は谷底を中心に配置されている：これら の配置状況を示したのが第 3 図である.

本研究ではその目的を達成するために, 流域内の 3 カ所の地点において流出量を測定した. 流域から の全流出量は, 流域内の恒常水流の最下流端に設置 した $90^{\circ}$ の三角堰 (n) によって測定される.この三 角堰の上流約 $15 \mathrm{~m}$ の地点に 5 インチのパーシャル型 流量計 $\left(\mathrm{P}_{5}\right)$ を設置し, さらに $\mathrm{P}_{5}$ の上流約 $35 \mathrm{~m}$ の地 点に 3 インチのパーシャル型流量計 $\left(\mathrm{P}_{3}\right)$ を設置した. $\mathrm{P}_{3}$ を設置した地点は水流の最源流部にあたり：この 


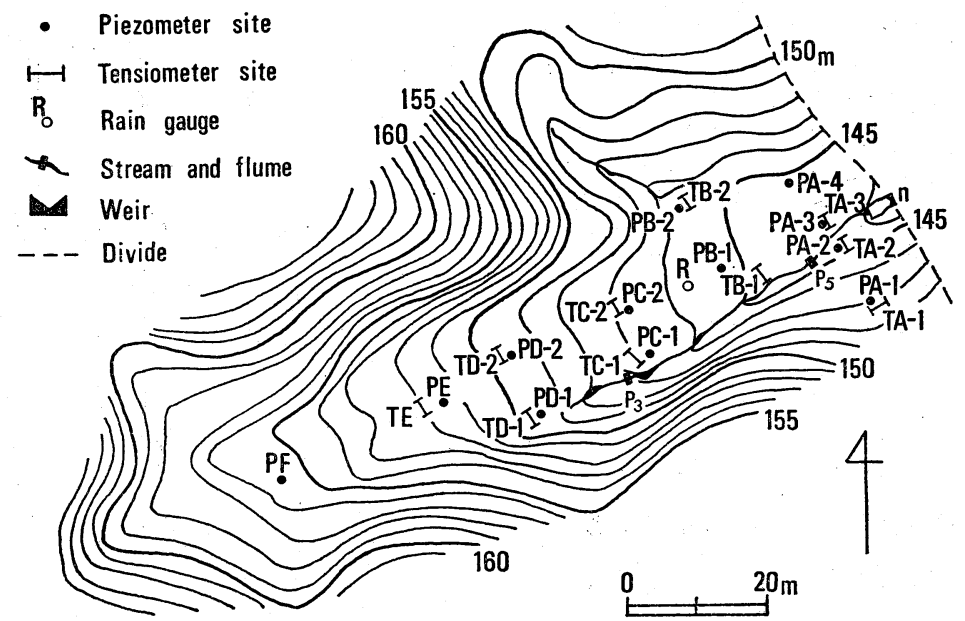

第3図観測施設の配 置

Fig. 3 Map of the valley floor studied

上流約 $10 \mathrm{~m}$ の地点から地下水が seep 状に常に流出 している.

降水量は, 谷底のほぼ中央に設置した転倒ます型 自記雨量計によって測定した. 第 3 図に示したその 他の観測施設についてはすでに報告したとおりであ る(Tanaka et al., 1981; 田中ほか, 1982).

\section{III 台風8124号に伴う流出}

調查は1981年 7 月から10月にかけて実施した。こ の間， 7 月 2 日〜 4 日の総降水量 $57.0 \mathrm{~mm}, 7$ 月 21 日の同 $46.5 \mathrm{~mm} ， 8$ 月20日〜23日の同77.0 $0 \mathrm{~mm}$ (台 風 8115 号)，8月 28 日の同 $20.0 \mathrm{~mm}, 9$ 月 4 日〜 5 日の同 $25.5 \mathrm{~mm}, 10$ 月 22 日 23 日の同 $172.5 \mathrm{~mm}$ (台風8124号)の 6 回の主な降雨を対象にして，それ ぞれについて流出量, 地下水位, 土壌水の圧力水頭, 地表流の発生状況等の野外観測を実施した. ここで は，最も代表的な台風8124号に伴う観測結果につい て述べる.

台風8124号は，10月22日夜半に関東に最接近した。 降雨は 22 日 6 時より降り始め，23 日 0 時までに総 降水量 $172.5 \mathrm{~mm}$ を記録した:この間, 1 回の小降 雨期をはさんで，22日16〜17時と21～22時の 2 回に

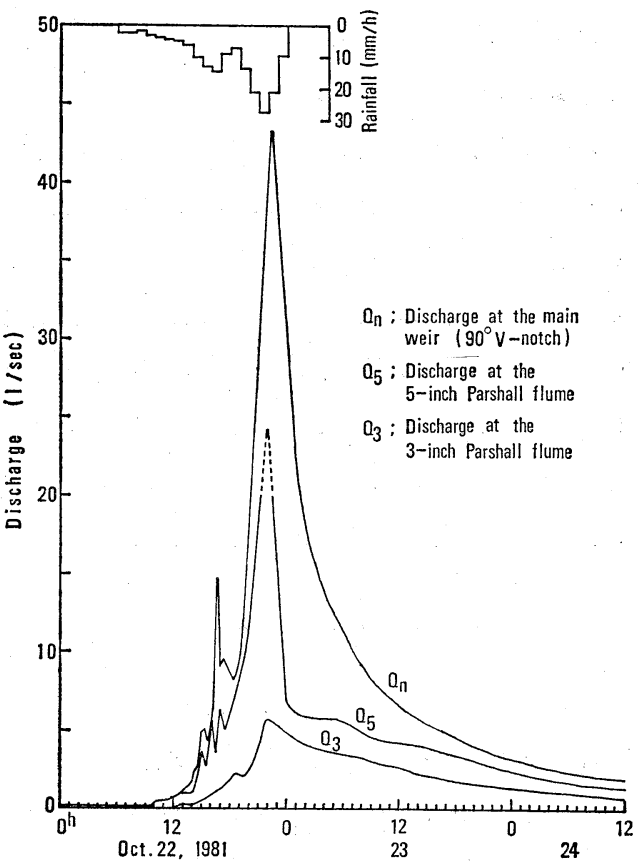

第 4 図台風 8124 号に伴う各流量観測地点の ハイドログラフ

Fig. 4 Discharge hydrographs for the storm event on October 22, 1981

わたって降雨のピークを形成している. それぞれの 降雨強度は, $14.5 \mathrm{~mm} / \mathrm{hr}, 27.5 \mathrm{~mm} / \mathrm{hr}$ であった 。 この降雨に伴う各流量観測地点でのハイドログラ 
第 1 表 台風 8124 号に伴弓流出量

Table 1 Amounts of discharge for the storm event on October 22, 1981

\begin{tabular}{l|c|c}
\hline & $\begin{array}{l}\text { Total amount of discharge } \\
\text { from 0900h, October 22 to } \\
1200 \mathrm{~h}, \text { October 24, 1981 }\end{array}$ & $\begin{array}{c}\text { Percentage of } \\
\text { discharge to } \Sigma Q_{\mathrm{n}}\end{array}$ \\
\hline$\Sigma Q_{\mathrm{n}}$ & $1,555 \mathrm{~m}^{3}$ & \\
$\Sigma Q_{5}$ & $852 \mathrm{~m}^{3}$ & $54.8 \%$ \\
$\Sigma Q_{3}$ & $392 \mathrm{~m}^{3}$ & $25.2 \%$ \\
\hline
\end{tabular}

フを示したのが第 4 図である.それぞれの八イドロ グラフは，いずれも降雨のピークに対応した鋭敏な ピークを形成し，降雨終了と同時に減水曲線を描い ている.

ここで， $\mathrm{n}$ を通過する流量を $Q_{\mathrm{n}}, \mathrm{P}_{5}$ を通過する 流量を $Q_{5}, \mathrm{P}_{3}$ を通過する流量を $Q_{3}$ とし，10月 22 日 9 時から 24 日12時までの $\Sigma Q_{\mathrm{n}}, \Sigma Q_{5}, \Sigma Q_{3}$ の值を示 すと第 1 表のようになる.

$\Sigma Q_{\mathrm{n}}$ は台風 8124 号に伴う流域からの総流出量で ある. 仮に, この全量が降雨直後の短期間の総流出 を意味しているものとすれば，流出率 ${ }^{1)}$ ( $41 \%$ とな る. 1980 年に観測された 4 回の主な降雨 (総降水量 $60.5 \sim 195.0 \mathrm{~mm}$ の範囲) についての流出率の值も ほぼ同じであった(田中ほか，1982)。このことから， 本流域においては，総降水量の約 $40 \%$ に相当する水 が降雨直後に流出するものと考えられる.

\section{IV 降雨流出時の流出成分}

\section{1 ）三角堰周辺からの地下水流出 ${ }^{22}$}

本流域における $\mathrm{n}$ と $\mathrm{P}_{5}$ の相対的関係を模式断面 として示したのが第 5 図である. この図に示すよう に, $Q_{\mathrm{n}}$ の構成成分は近似的に次式によって表わさ れる。

$$
Q_{\mathrm{n}} \simeq Q_{5}+Q_{\mathrm{n}, \mathrm{G}}
$$

ここで, $Q_{\mathrm{n}, \mathrm{G}}$ は三角堰周辺からの地下水流出量で ある。

三角揠壁面の露頭状況を1982年 1 月の時点におい てスケッチしたものが第 6 図である. 図から明らか

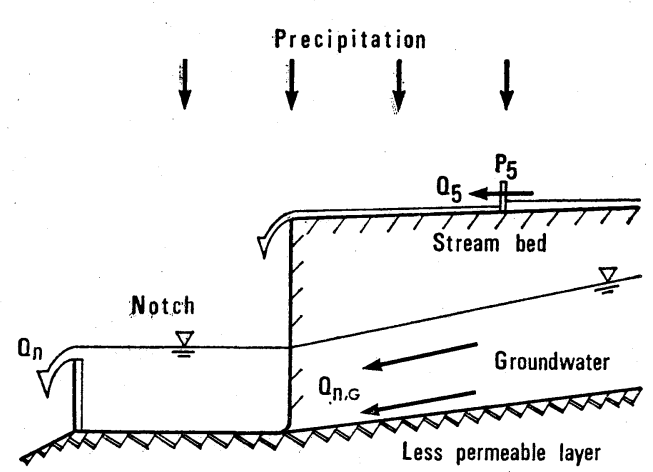

第 5 図 三角堰 (n) と 5 インチパーシャル型流 量計設置地点 $\left(\mathrm{P}_{5}\right)$ の関係を示す模式断 面

Fig. 5 Schematic diagram showing the relationship between the main weir $\left(90^{\circ} \mathrm{V}\right.$ notch, $n)$ and 5-inch Parshall flume $\left(P_{5}\right)$

なように，礫層下位のシルト質粘土層中および両者 の境界付近に多数のパイプが存在している様子がわ かる. 最大のもの(以下，マスターパイプと呼ふ)は， 長軸 $30 \mathrm{~cm}$, 短軸 $10 \mathrm{~cm}$ の楕円状を呈し(第 6 図-(B), このマスターパイプを通じて, 三角堰への地下水流 出が常時存在することが野外観察によって確認され ている.

式(1)より， $\left(Q_{\mathrm{n}}-Q_{5}\right)$ は三角揠周辺からの地下水 流出量と考えることができる. 台風 8124 号に伴う $\left(Q_{\mathrm{n}}-Q_{5}\right)$ の経時変化を, $Q_{\mathrm{n}}$ のハイドログラフと ともに示したのが第 7 図である. また, $Q_{\mathrm{n}} / Q_{5}$ の経 時変化を示したのが第 8 図である. 第 7 図から明ら かなように, 三角揠周辺からの地下水流出は $Q_{\mathrm{n}}$ の ハイドログラフと同様な形態を示し，ピーク時には $25 l / \sec$ 以上の多量の流出を生じている. 地下水流 出のピークは $Q_{\mathrm{n}}$ のピークより約 90 分遅れて出現し (第 7 図), このピーク時には $Q_{5}$ の 4 倍以上の流量 を生じている(第 8 図).

第1表に示したように， $\Sigma Q_{\mathrm{n}}$ は $1,555 \mathrm{~m}^{3} ， \Sigma Q_{5}$ は $852 \mathrm{~m}^{3}$ である. したがって， $\Sigma Q_{\mathrm{n}, \mathrm{G}}$ は $703 \mathrm{~m}^{3}$ となり, 台風 8124 号に伴う総流出量の実に $45 \%$ に相 当する多量の地下水流出が，三角揠周辺において生 


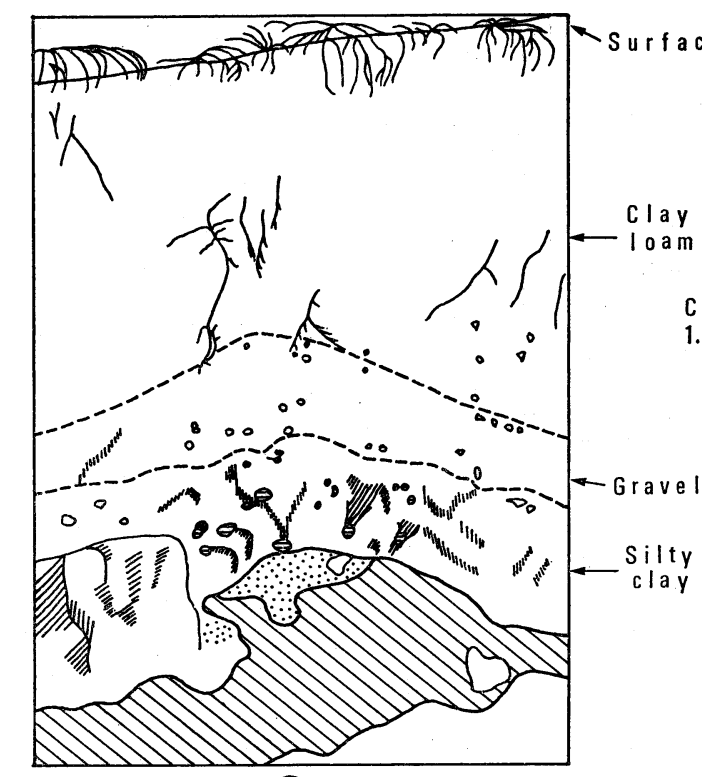

(A)

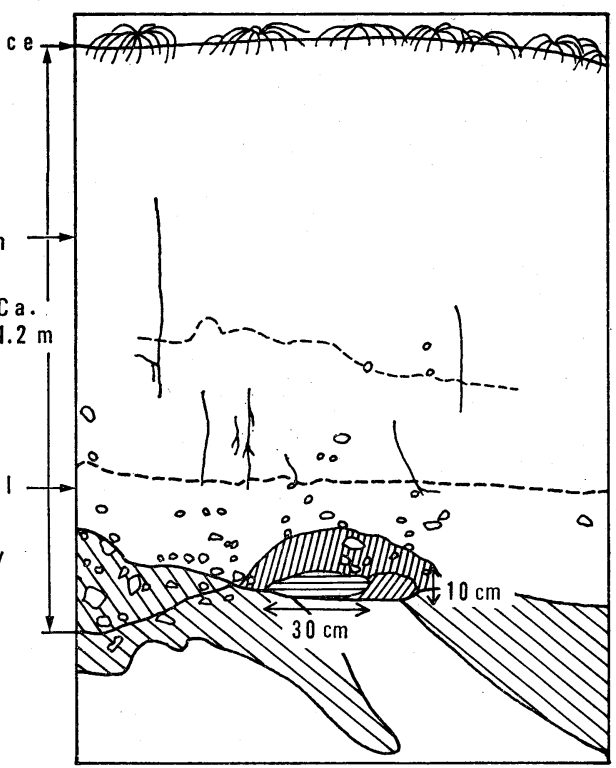

(B)

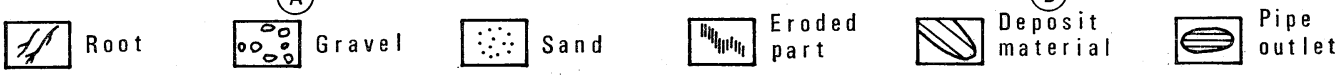

第 6 図 三角揠壁面露頭に扮けるパイプの分布 (1982 年 1 月時点)

Fig. 6 Pipe distributions on banks around the main weir (Jan., 1982)

じていることが明らかである.こうした降雨に対す る応答の早い多量の地下水流出現象が降雨流出時に 存在することはこれまでにも環境同位体を用いた 流出解析において指摘されていた（例えば，Fritz et al., 1976; Sklash and Farvolden, 1979 ; 田中ほ か，1980；Rodhe, 1981 など)が，実測された例はき わめて少ない。

\section{2) $Q_{5}$ のハイドログラフ構成成分}

前節において，三角揠周辺からの地下水流出量を 明らかにすることができた。流域からの総流出量の $55 \%$ は $P_{5}$ を通過する流量に相当するが，この $P_{5}$ 通 過流量 $\left(Q_{5}\right)$ は次式によって表わされる.

$$
Q_{5}=Q_{3}+Q_{5, \mathrm{~S}}+Q_{3 \sim 5, \mathrm{G}}
$$

ここで, $Q_{3}$ は $\mathrm{P}_{3}$ を通過する流量, $Q_{5, \mathrm{~s}}$ は直接河道 降雨と地表流を含む表面流出量, $Q_{3 \sim 5, \mathrm{G}}$ は $\mathrm{P}_{3}$ と $\mathrm{P}_{5}$ の区間において，谷底面および側方斜面の地下水帯 から河道へ供給される地下水流出量である. 後述す るように, 式(2)中の $Q_{3}$ は, その全量が地下水流出
であるから，式(2) は次式のように書き改めること ができる.

$$
\begin{aligned}
Q_{5} & =Q_{5, \mathrm{~S}}+\left(Q_{3 \sim 5, \mathrm{G}}+Q_{3, \mathrm{G}}\right) \\
& =Q_{5, \mathrm{~S}}+Q_{5, \mathrm{G}}
\end{aligned}
$$

ここで, $Q_{5, G}$ は $Q_{3, G}$ を含んで $P_{5}$ を通過する地下 水流出総量である. 降雨流出時における流域からの 流出成分を考察するためには， $Q_{5}$ を式(3) 右辺の各 流出成分に分離する必要がある.

今，降雨流出時の流出成分が，地表流と直接河道 降雨を含む表面流出成分と地下水流出成分との二成 分から構成されているものとすれば33，河川のある 特定断面に执いて次の二つの収支式が成り立つ.

$$
\begin{aligned}
& Q_{\mathrm{T}}=Q_{\mathrm{S}}+Q_{\mathrm{G}} \\
& C_{\mathrm{T}} Q_{\mathrm{T}}=C_{\mathrm{S}} Q_{\mathrm{S}}+C_{\mathrm{G}} Q_{\mathrm{G}}
\end{aligned}
$$

ここで， $Q$ は流量, $C$ はトレーサーの濃度を表わし， 添字 $\mathrm{T}, \mathrm{S}, \mathrm{G}$ はそれぞれ総流出, 表面流出, 地下水 流出の各成分を表わす. 式(4)および式(5)より，地 下水流出量 $Q_{G}$ は, 


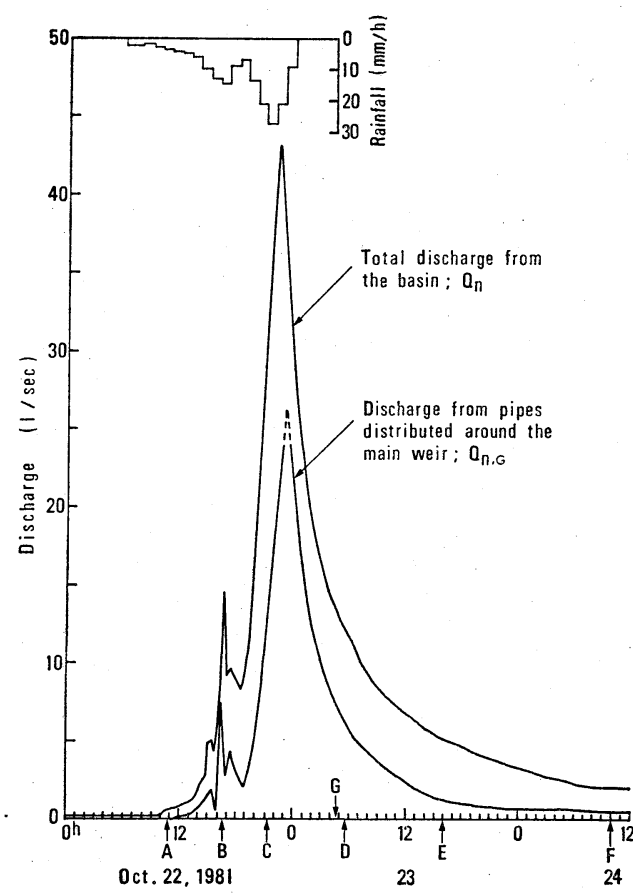

第 7 図 台風 8124 号に伴う $Q_{\mathrm{n}}$ と $Q_{\mathrm{n}, \mathrm{G}}$ の ハイドログラフ

図中の矢印は流線網解析時刻およびパイプ流 量計算時刻を示す. $A \sim F$ : 流線網解析 (第 2 表参照) $\mathrm{G}$ : パイプ流量計算(第 3 表参照)

Fig. 7 Discharge hydrographs of $Q_{\mathrm{n}}$ and $Q_{\mathrm{n}, \mathrm{G}}$ for the storm event on October 22, 1981 Arrows indicate the times of performed flow net analyses ?and calculation of pipe flow discharge. A F : flow net analyses (see Table 2) G: calculation of pipe flow discharge (see Table 3)

$$
Q_{\mathrm{G}}=\left(\frac{C_{\mathrm{T}}-C_{\mathrm{S}}}{C_{\mathrm{G}}-C_{\mathrm{S}}}\right) Q_{\mathrm{T}}
$$

で表わされる. $C_{\mathrm{T}}, C_{\mathrm{G}}, C_{\mathrm{S}}$ および $Q_{\mathrm{T}}$ を実測するこ とにより，式(6)と式(4)を用いて，降雨流出時にお ける表面流出成分と，地下水流出成分を分離するこ とが可能となる4)．本研究においては，トレーサー として流水の電気伝導度を用いた。

台風8124号に伴う $Q_{5}$ のハイドログラフおよび電 気伝導度の経時変化を第 9 図に示す. 電気伝導度の 値は，水温 $18^{\circ} \mathrm{C}$ の值に補正して表わしてある.

流水の電気伝導度は, 降雨強度に敏感に対応して 増減を繰り返し, 流出初期の段階で $39.4 \mu \mathrm{S} / \mathrm{cm}$ と

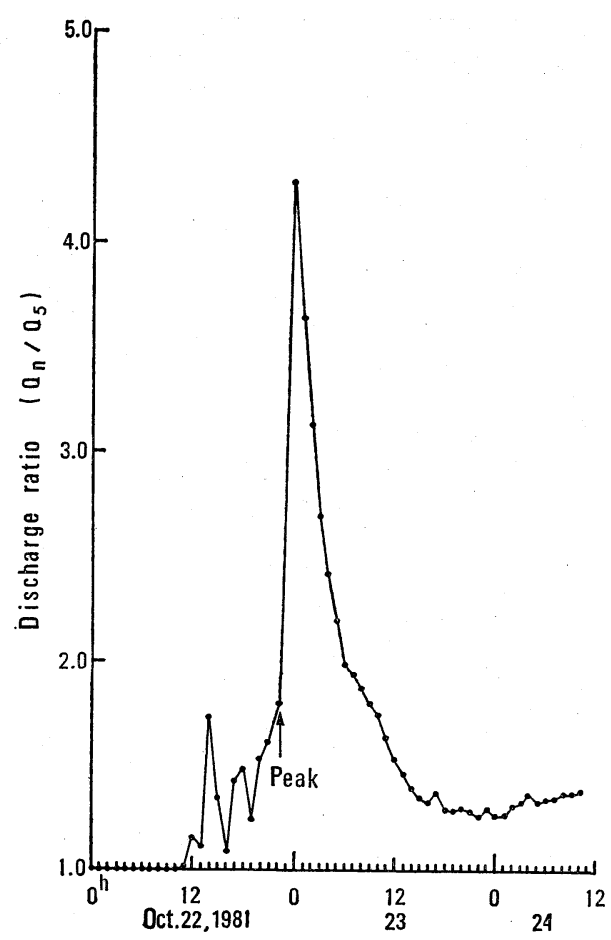

第 8 図 $Q_{n} / Q_{5}$ の経時変化

Fig. 8 Time variation of $Q_{\mathrm{n}} / Q_{5}$

最低值を記録している. 流出ピーク時の值は 48.5 $\mu \mathrm{S} / \mathrm{cm}$ であり, 流出初期の最低值よりは高く, 河 川流量が増大しているにもかかわらず，流水の電気 伝導度は上昇する傾向にある. 降雨が終了すると同 時に, 電気伝導度は再び増加し, ハイドログラフの 減水部において降雨開始以前の值に回復している.

第 9 図から，本流域における無降雨時の流水の電 気伝導度は, $60 \sim 70 \mu \mathrm{S} / \mathrm{cm}$ 程度の值を維持してい るものと考えられる.このことから, 式(6)中の $C_{\mathrm{G}}$ として, 無降雨時の值を平均した $65.3 \mu \mathrm{S} / \mathrm{cm}$ を用いた。 また, 地表流の電気伝導度 $\left(C_{\mathrm{S}}\right)$ は, 降水 のそれに等しいと仮定し, 調査期間中に集めた降水 の電気伝導度の值から $20 \mu \mathrm{S} / \mathrm{cm}$ とした。これらの 值と実測された $Q_{\mathrm{T}}, C_{\mathrm{T}}$ を用いて，式(6) と式(4)に よって， $Q_{5}$ のハイドログラフを分離した結果が, 第 9 図に示されている. 


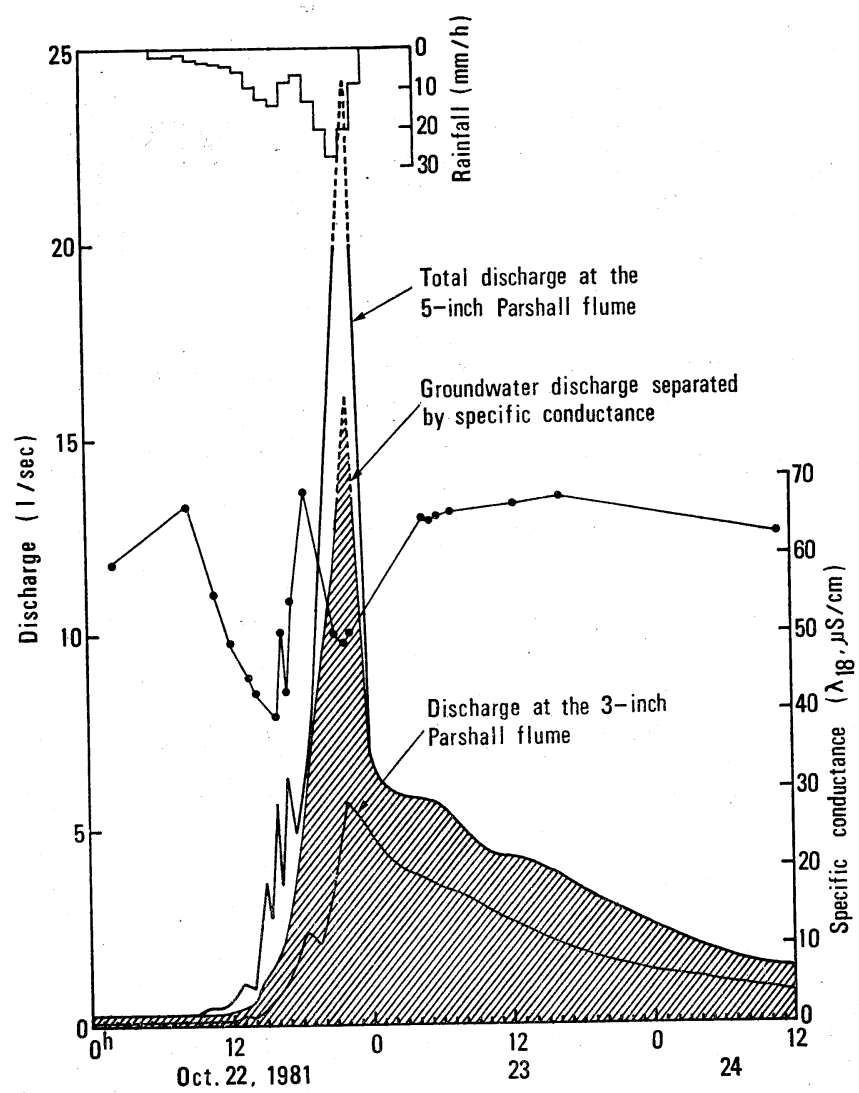

第 9 図電気伝導度による $Q_{5}$ のハイドログラフの分離結果

Fig. 9 Separated hydrograph of $Q_{5}$ using specific conductance

この結果, $P_{5}$ を通過する地下水総流出量 $\left(\Sigma Q_{5, \mathrm{G}}\right)$ は $734 \mathrm{~m}^{3}$ に達し， $\Sigma Q_{5}$ の $86 \%$ が地下水流出成分 によって占められていることになる。 $\Sigma Q_{5}$ の $14 \%$ ， $118 \mathrm{~m}^{3}$ が $\mathrm{P}_{5}$ を通過する表面流出総量となる.

一方, $\mathrm{P}_{5}$ での流出に関与する地表流発生域の総面 積卓は,これまでの観測結果から, 最大約 $650 \mathrm{~m}^{2}$ で あることが明らかにされている(田中ほか，1982). 今, この部分に降った降雨がすべて表面流出するも のとすれば，台風8124号の場合，その総量は約 112 $\mathrm{m}^{3}$ となる. この值は, 電気伝導度をトレーサーに して分離された $Q_{5}$ の表面流出総量 $118 \mathrm{~m}^{3}$ に，ほぼ 一致する.

一般に，電気伝導度をトレーサーとするハイドロ グラフの分離方法では, 雨水と土壤粒子との接触に
よる溶存物質の濃度変化, あるいは異なる流出成分 中に存在する物質間での化学変化等を考慮する必要 があり,この方法による分離結果は地下水流出成分 を過大に評価するとの指摘がなされている(Pilgrim et al., 1979). しかし, 本流域においては, むしろ 表面流出成分が過大に評価されている可能性があ $\eta^{6)}$, これまでの研究結果と異なる.これは, 本流 域が人工の手の加わらない自然流域であり, 地表面 への施肥等が行なわれていないこと, 植生が密であ るため, 雨水と土粒子の接触による溶存物質の濃度 変化がそれ程大きくはなかったこと，等によるもの と考えられる.また, 流出期間中の電気伝導度は, $39.0 \mu \mathrm{S} / \mathrm{cm}$ から $68.5 \mu \mathrm{S} / \mathrm{cm}$ の間で変動しており, その変動幅は小さく, 異なる流出成分中に含まれる 


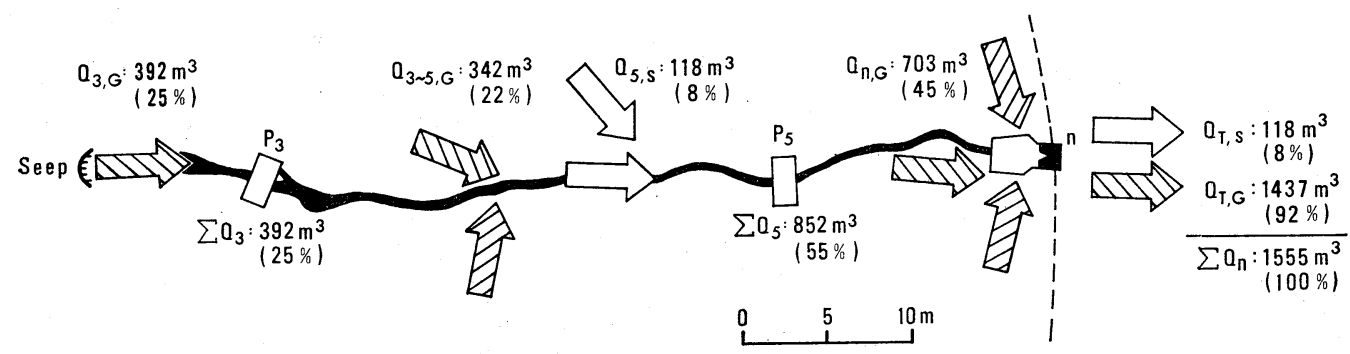

第 10 図流量観測地点間の流出量の割合とその構成成分

（）内の数値は $\Sigma Q_{\mathrm{n}}$ に対する割合を示す。

Fig. 10 Discharge ratios and flow components between two adjacent discharge observation points

Figures in the parentheses represent the percentages of discharges to $\Sigma Q_{n}$.

溶存物質の間での化学変化が，解析結果に影響を与 える程には生じていなかったものと判断される.こ れらのことから，本試験流域においては，電気伝導 度は理想的なトレーサーになりえたものと考えられ， $Q_{5}$ のハイドログラフの分離結果は, ほぼ妥当な值 を示しているものと判断される.

3) $Q_{3}$ のハイドログラフ構成成分

$\mathrm{P}_{3}$ の上流においては，地表流の流入はなく，また， $\mathrm{P}_{3}$ より上流の水流面積は最大で約 $5 \mathrm{~m}^{2}$ 程度であり,

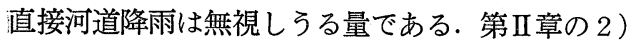
で述べたように, $\mathrm{P}_{3}$ の上流約 $10 \mathrm{~m}$ の地点からはseep 状の地下水流出の存在が確認されている.こうした ことから， $Q_{3}$ はその全量が源流部における seep 状 の地下水流出であると考えることができる. したが って，Q $Q_{3}$ は次式のように表わすことができる.

$$
Q_{3} \simeq Q_{3, \mathrm{G}}
$$

ここで, $Q_{3, G}$ は $P_{3}$ を通過する地下水流出量である.

第1表に示したように, $\Sigma Q_{3} \simeq \Sigma Q_{3, \mathrm{G}}$ は $392 \mathrm{~m}^{3}$ である.したがって， $\Sigma Q_{5}$ の $46 \%, \Sigma Q_{\mathrm{n}}$ の $25 \%$ は 最源流部からの seep 状の地下水流出によって占め られていることになる. また，前節で明らかにした ように, $\Sigma Q_{5, \mathrm{G}}$ は $734 \mathrm{~m}^{3}$ であった. $\Sigma Q_{5, \mathrm{G}}$ は $\left(\Sigma Q_{3}\right.$ $\left.\sim 5, G+\Sigma Q_{3, G}\right)$ として表わされるから, 源流部からの 地下水流出は $\mathrm{P}_{5}$ を通過する地下水総流量の $53 \%$ を 沾めていることになり, 残りの $47 \%, 342 \mathrm{~m}^{3}$ が $\mathrm{P}_{3}$
と $\mathrm{P}_{5}$ の区間において河道へ供給された地下水流出 量となる.

一方, 第 9 図に示すように, 電気伝導度をトレー サーにして分離した $Q_{5}$ の地下水流出成分は, $Q_{3}$ の 全量を包含しており， $Q_{3}$ の流出成分を考えると $Q_{5}$ の分離結果は矛盾していないことがわかる.

4 ）流量観測地点間における流出量の割合と その構成成分

これまでの考察から, 流量観測地点間における流 出量の割合およびその構成成分が明らかとなった。 この結果を模式的に表わしたのが第10図である.

地表流は $\mathrm{P}_{3}$ と $\mathrm{P}_{5}$ の区間において生じているだけ であり, 直接河道降雨を含めた表面流出が総流出量 に占める割合はわずか $8 \%$ にすぎない，総流出量の 92\%は地下水流出成分によって構成されている，流 量観測地点間における地下水流出の割合は，三角堰 周辺からの流出が $703 \mathrm{~m}^{3}$ で, 総地下水流出量の 49 $\%, \mathrm{P}_{3}$ と $\mathrm{P}_{5}$ の区間に抢ける流出が $342 \mathrm{~m}^{3}$ で $24 \%$ ， $\mathrm{P}_{3}$ 上流の源流部からの流出が $392 \mathrm{~m}^{3}$ で $27 \%$ であ る.

$Q_{\mathrm{n}}$ を構成する地下水流出成分 $Q_{\mathrm{T}, \mathrm{G}}$ は次式によ って求めることができる.

$$
\begin{aligned}
Q_{\mathrm{T}, \mathrm{G}} & =Q_{3, \mathrm{G}}+Q_{3 \sim 5, \mathrm{G}}+Q_{\mathrm{n}, \mathrm{G}} \\
& =Q_{5, \mathrm{G}}+Q_{\mathrm{n}, \mathrm{G}}
\end{aligned}
$$

前節までに得られた結果に基つ゚いて， $Q_{\mathrm{T}, \mathrm{G}}$ を $Q_{\mathrm{n}}$ 


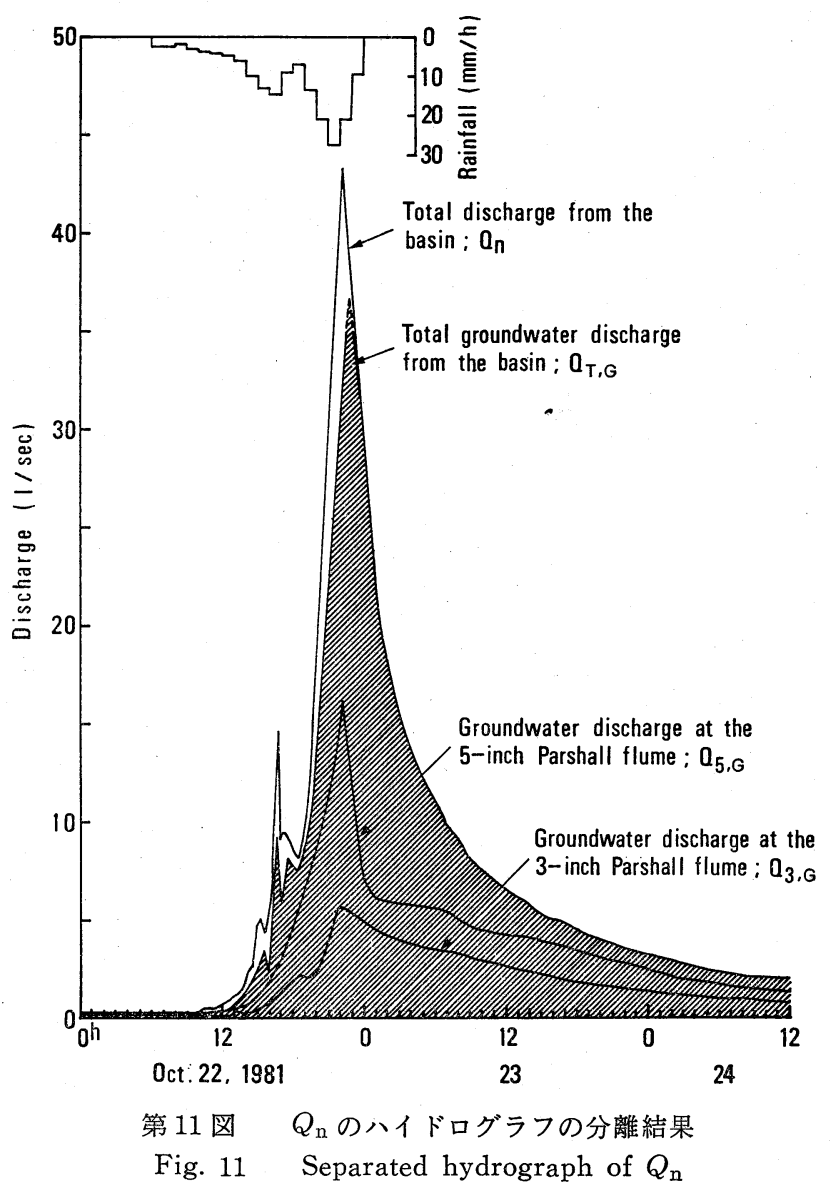

のハイドログラフから分離して示したのが，第11図 である. ハイドログラフの上昇部において，わずか に表面流出に起因する流出成分が存在するが，減水 部の大部分は地下水流出成分によって占められてい ることがわかる. 第11図にみられる地下水流出の特 徴は, 降雨に対する応答が早く, しかも多量の流出 を生じていることである.

\section{V 降雨流出時における地下水流出機構}

\section{1) 流線網解析}

これまでの考察から，降雨流出時において降雨に 対する応答が早く, しかも多量の地下水流出が生じ ていることが明らかとなった。この地下水の流出機 構を明らかにするため, 三角堰周辺からの地下水流
出現象を対象にして，ダルシー則に基づく流線網解 析を試み，従来の地下水流動理論によって，その流 出現象が説明できるか否かを検討する.

第12図は, 台風8124号に伴う地下水面等高線の経 時変化を示したものである.この図から，降雨流出 時において，谷底および側方斜面を流下する地下水 は，最終的には三角堰周辺に集中する流れであるこ とがわかる。

第 13 図は，流出がピークに達する約 1 時間前(10 月 22 日 21 時 10 分）の三角堰周辺における地下水面等 高線を拡大したものである. 地下水の流動系が，二 次元近似できるものとすれば，この地下水面等高線 に直交する形で流線を描くことができ，流線網を作 成することが可能である．この流線網を用いること 

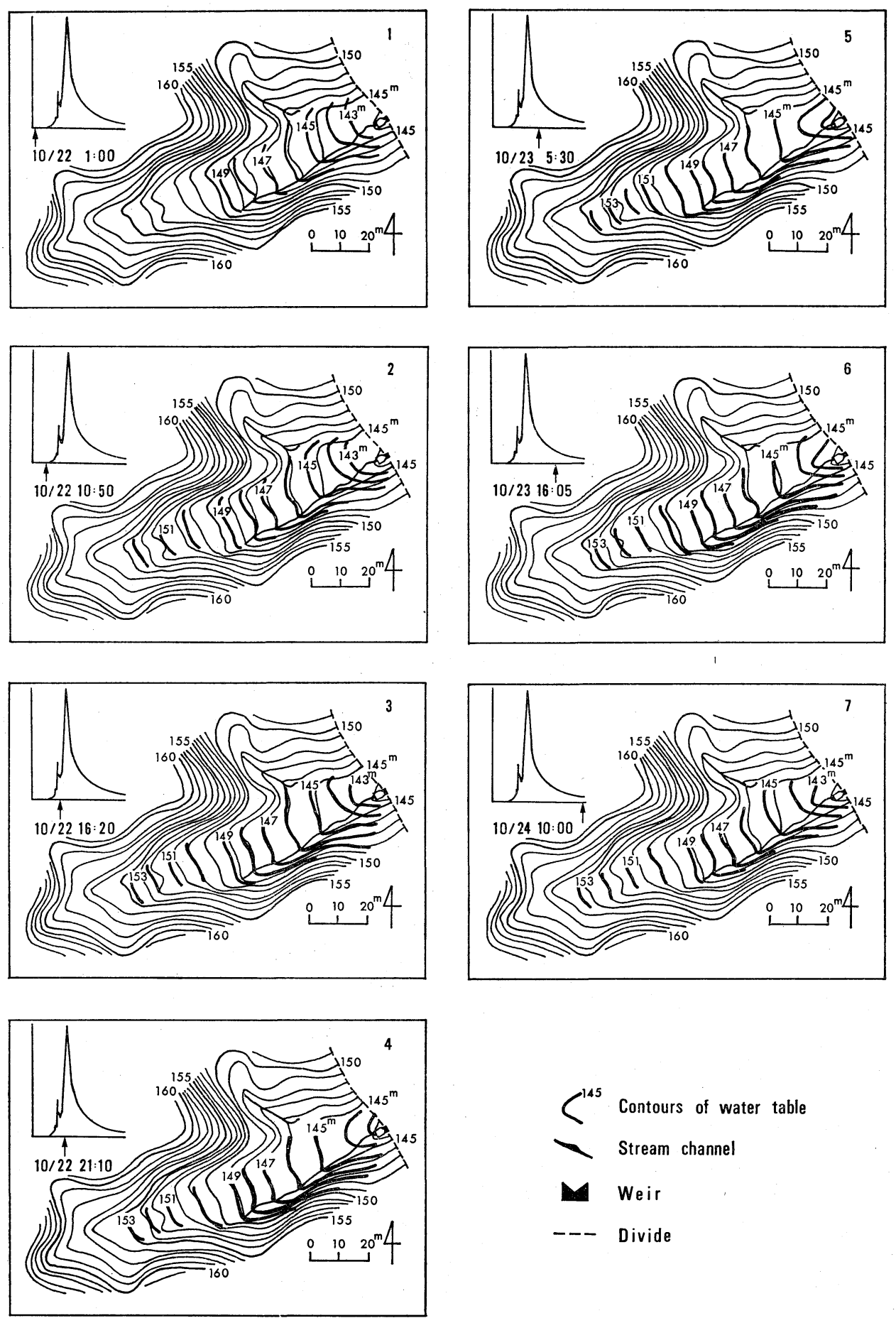

第 12 図 台風 8124 号に伴亏地下水面等高線の経時変化

Fig. 12 Contour maps of water table during the storm event on October 22, 1981 


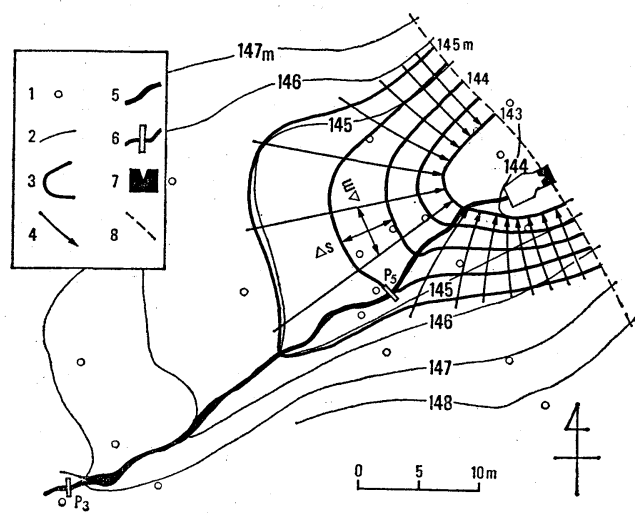

第 13 図 三角堰周辺に打ける地下水面等高線と 流線網(10月 22 日, 21 時 10 分)

1. 観測井 2. 地形等高線 3. 地下水面等高線 4. 流線 5. 河道 6 . パーシャル型流量計 7 . 三角堰 8. 流域境界

Fig. 13 Contour map of water table and flow nets around the main weir at 2110 h, October 22, 1981

1. observation well 2. contour line 3. contour of water table 4. flow line 5. stream channel 6. Parshall flume 7. main weir 8. divide

によって，ダルシー則に基づいて三角垵へ流入する 地下水流出量を計算することができる.すなわち， 流線間の単位厚さの流通断面を通過する流量 $\Delta q$ は, ダルシーの法則により次式で計算することができる.

$$
\Delta q=K(\Delta h / \Delta s) \Delta m
$$

ここで, $K$ は透水係数, $\Delta h$ は等高線間の水理水頭 差, $\Delta s$ は流線に平行な等高線間の距離, $\Delta m$ は等高 線に平行な流線間の距離である.また, $\Delta s=\Delta m$ な る矩形によって, $n$ 個の流線網に分割された流通断
面を通過する総流出量 $Q_{\mathrm{f}}$ は，次式によって求める ことができる.

$$
\begin{aligned}
Q_{\mathrm{f}} & =n \cdot w \cdot \Delta q \\
& =K \cdot w \cdot n \cdot \Delta h \\
& =T \cdot n \cdot \Delta h
\end{aligned}
$$

ここで, $n$ は流線網の数, $w$ は流通断面の厚さ, $T$ は透水量係数である.

第13図に示した解析領域における流通断面の厚さ (帯水層層厚)は, 最大約 $2 \mathrm{~m}$ である，また，この層 準における土壌サンプルから得られた透水係数の最 大值は $3.70 \times 10^{-6} \mathrm{~m} / \mathrm{sec}$ である.したがって，第 13 図に示した時刻において流線網解析より得られる三 角揠への地下水流出量は式(10)より,

$$
\begin{aligned}
Q_{\mathrm{f}} & =3.70 \times 10^{-6} \times 2 \times 16 \times 0.5 \\
& =5.92 \times 10^{-5}\left(\mathrm{~m}^{3} / \mathrm{sec}\right)
\end{aligned}
$$

となる.この值は，22日21時10分時点においてダル シ一則に基づいて三角堰へ流出する地下水流量の最 大值を示しているものと考えることができる.

一方，この時刻において実測された三角堰周辺か らの地下水流出量は, $1.30 \times 10^{-2} \mathrm{~m}^{3} / \mathrm{sec}$ である. 流線網解析によって得られた計算値は, 実測值より も 3 オーダ程小さな值を示していることになる.

第 2 表は，流線網解析による計算值と実測值を比 較したものである $(\mathrm{A} \sim \mathrm{F}$ の対応時刻は第 7 図を参 照). 第 2 表と第 7 図から明らかなように，降雨前 の基底流出時においては，流線網解析結果は実測值 にほぼ等しく，この状態において地下水は,ダルシ

第 2 表 三角堰周辺からの地下水流出量の実測值と流線網解析結果の比較

Table 2 Comparisons of observed groundwater discharge around the main weir with calculated one by flow net analysis

\begin{tabular}{c|c|c|c|c}
\hline Date & Time & $\begin{array}{c}\text { Symbol in } \\
\text { Fig. 7 }\end{array}$ & $\begin{array}{c}\text { Observed } \\
\text { discharge } \\
(l / \mathrm{sec})\end{array}$ & $\begin{array}{c}\text { Calculated discharge } \\
\text { by flow net analysis } \\
(l / \mathrm{sec})\end{array}$ \\
\hline Oct. 22 & $1055 \mathrm{~h}$ & $\mathrm{~A}$ & $1.0 \times 10^{-2}$ & $4.4 \times 10^{-2}$ \\
& $1620 \mathrm{~h}$ & $\mathrm{~B}$ & $3.9 \times 10^{\circ}$ & $5.2 \times 10^{-2}$ \\
& $2110 \mathrm{~h}$ & $\mathrm{C}$ & $1.3 \times 10^{1}$ & $5.9 \times 10^{-2}$ \\
Oct. 23 & $0530 \mathrm{~h}$ & $\mathrm{D}$ & $6.3 \times 10^{0}$ & $5.2 \times 10^{-2}$ \\
& $1605 \mathrm{~h}$ & $\mathrm{E}$ & $1.3 \times 10^{\circ}$ & $4.8 \times 10^{-2}$ \\
Oct. 24 & $1000 \mathrm{~h}$ & $\mathrm{~F}$ & $5.0 \times 10^{-1}$ & $4.8 \times 10^{-2}$ \\
\hline
\end{tabular}




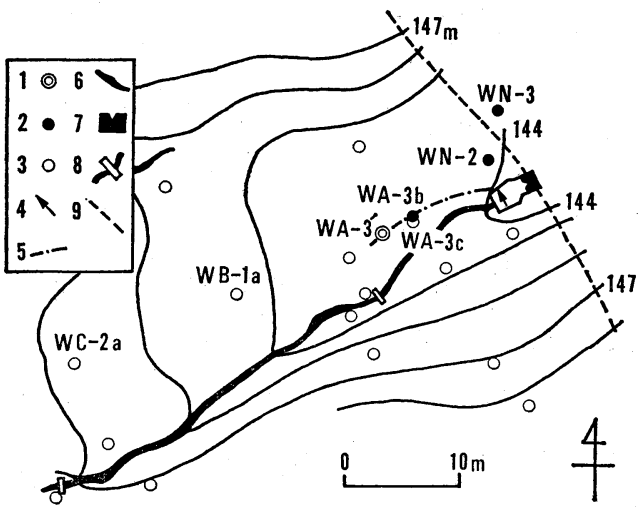

第 14 図 トレーサー実験観測施設の配置 1. トレーサー投入井 2 . 試水サンプリング井

3. 観測井 4. マスターパイプ出口採水地点

5. 推定されるマスターパイプの径路 6 . 河道 7. 三角堰 8. パーシャル型流量計 9. 流域境 界

Fig. 14 Locations of the injection well, sampling points and observation wells for the tracer experiments

1. injection well 2. sampling well 3 . observation well 4. sampling point at the outlet of the master pipe 5 . estimated course of the master pipe 6. stream channel 7. main weir 8. Parshall flume 9. divide

一則に基づいて流動しているといえる. しかし，降 雨流出時に実測された地下水流出量は, 流線網解析 によって計算された流出量に比較して，2〜3オーダ 程大きな值を示しており,ダルシー則に基づく地下 水流動だけでは, 多量の地下水流出現象を説明する ことができない.1981年に観測された他の 2 回の降 雨(総降水量 $58.0 \mathrm{~mm}$ と $77.0 \mathrm{~mm}$ )の解析例において も, 結果はまったく同様であった (丸井, 1982 BS).

以上の考察結果は, 降雨流出時においてはダルシ 一流よりはるかに速い卓越流が地層中に存在してい る可能性のあることを示唆している.

\section{2 ）卓越流の実流速}

降雨流出時に予想される卓越流の実流速を把握す るため, 蛍光染料(Sulpho-rhodamine B, CI 45100 および Lissamine FF，CI 56205）を用いたトレー サー実験を実施した。
野外観察によれば，降雨流出時における三角堰周 辺からの地下水流出の一部は, 第 6 図-(Bに示した マスターパイプを通じて流出している.トレーサー を用いた予備実験によって，このマスターパイプの 地層中の径路は，第14図に一点鎖線で示したような ものと予想された．このことから，実流速を把握す るためのトレーサー投入井，およびサンプリング井 を第14図に示すように配置した，実験方法ならびに トレーサー濃度分析方法については，すでに報告し たとおりである(Tanaka et al., 1982).

マスターパイプ出口におけるトレーサー濃度の分 析結果を示したのが第15図である. 10月23日 4 時 42 分に観測井 WA-3'第14図)に投入した Lissamine FF は, 1 分後の 4 時 43 分には約 $11 \mathrm{~m}$ 下流のマスタ 一パイプ出口において検出された. マスターパイプ 出口のトレーサー濃度は, 投入 8 分後にピークに達 し, 以後パルス状の濃度変化を繰り返している.

このトレーサー実験結果から, マスターパイプを 介した卓越流の最大流速（4 時 43 分時点）として $0.183 \mathrm{~m} / \mathrm{sec}$ という值を得る. 実験を実施した時間 が，ハイドログラフの減水部であるにもかかわらず， 地層中に打いて地表流に匹敵する速い流れが存在し ていることが明らかとなった。

マスターパイプ出口の断面積は $0.024 \mathrm{~m}^{2}$ である. したがって 4 時43分時点において，このパイプから 流出している流量は $4.4 \mathrm{l} / \mathrm{sec}$ となる. 一方, この 時刻において, 三角堰周辺からの地下水流出量は $6.8 l / \mathrm{sec}$ (第 7 図，G抢よび第 3 表) であり，マスタ 一パイプからの流出量だけで三角堰周辺からの全地 下水流出量の $65 \%$ を占めていることになる. 第 6 図 に示したように, 三角揠壁面にはこのマスターパイ プの他に大小多数のパイプが存在している. ダルシ 一流では説明できなかっった降雨流出時の多量の地下 水流出は，こうした地層中に形成されたパイプの中 を流れるパイプ流として流出しているものと考える ことができる. 


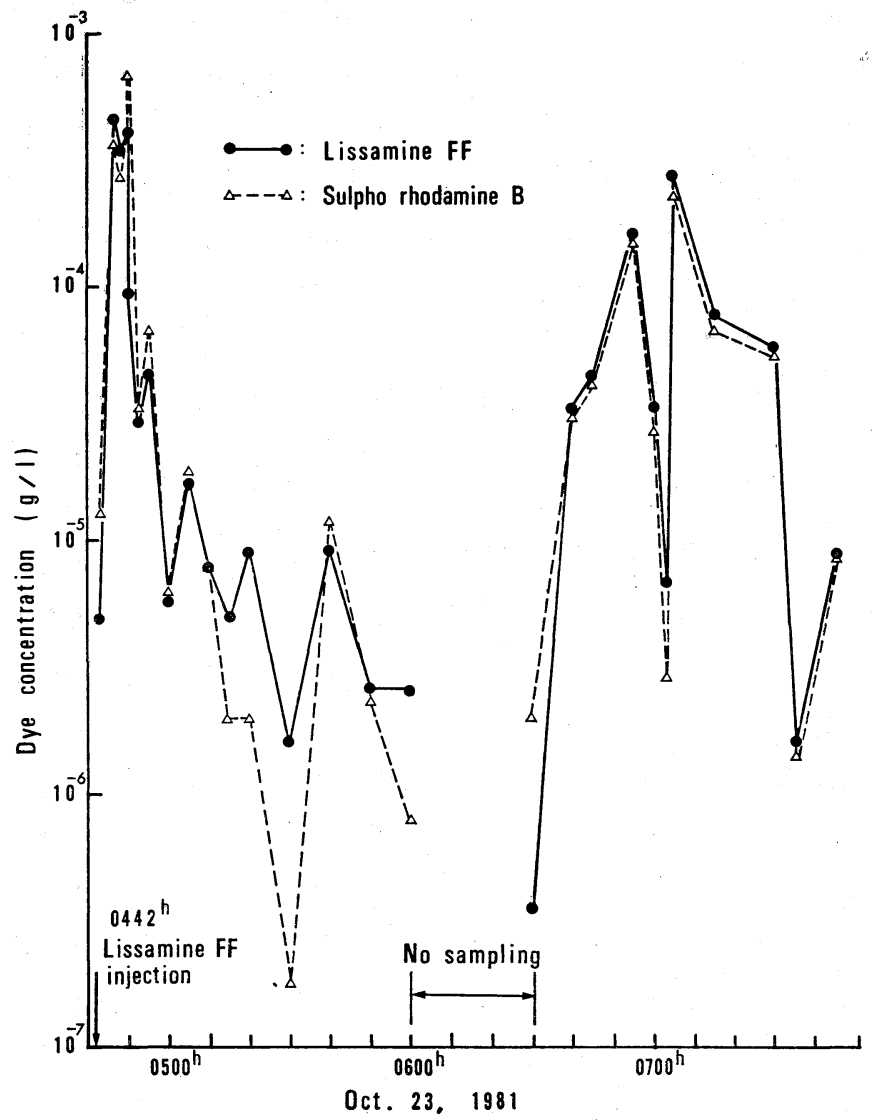

第 15 図 マスターパイプ出ロのトレーサー濃度分析結果

Fig. 15 Time variations of dye concentrations in pipe flow sampled at the outlet of the master pipe

第 3 表 三角堰周辺からの地下水流出量の実測值とマスターパイプ からのパイプ流量計算結果の比較

Table 3 Comparison of observed groundwater discharge around the main weir with calculated pipe flow discharge at the outlet of the master pipe

\begin{tabular}{c|c|c|c|c}
\hline Date & Time & $\begin{array}{c}\text { Symbol in } \\
\text { Fig. } 7\end{array}$ & $\begin{array}{c}\text { Observed } \\
\text { discharge } \\
(l / \mathrm{sec})\end{array}$ & $\begin{array}{c}\text { Calculated pipe flow } \\
\text { discharge } \\
(l / \mathrm{sec})\end{array}$ \\
\hline Oct. 23 & $0443 \mathrm{~h}$ & $\mathrm{G}$ & 6.8 & 4.4 \\
\hline
\end{tabular}

なお，第15図に示したトレーサー濃度にパルス状 の濃度変化が記録されている.この現象は pulsating flow と呼ばれ (Jones, 1978), パイプ流の 特徴であるがここれに関してはすでに報告した
(Tanaka et al., 1982)ので, 本論文では割愛する.

\section{VI 考察}

前述したように，降雨流出あるいは融雪出水時に 
おける地下水流出の重要性は，環境同位体を用いた 流出解析 (Dinçer et al., 1970; Martinec et al., 1974 ; Fritz et al., 1976; Sklash and Farvolden, 1979; 田中ほか, 1980 ; Herrmann and Stichler, 1980 ; Rodhe, 1981)や水温をトレーサーにした流 出解析(Kobayashi，1981)、において指摘されていた。 これらの研究の多くは湿潤森林流域を対象としたも のであり，その流域面積は $1.2 \mathrm{~km}^{2}$ から $83.0 \mathrm{~km}^{2}$ の範囲にわたっている. そして,これらの研究結果 によれば，対象流域を問わず，総流出量に占める地 下水流出量の割合は $60 \sim 90 \%$ であること, 流出ピー ク時に地下水流出成分が占める割合は, やはり60 $80 \%$ であることが共通の結論として得られており （田中，1982），本研究の場合も，現象面からはこれ らの解析結果と同じ結論に達する.

こうした降雨に伴う応答の早い多量の地下水流出 現象を説明する流出機構については, 現在二つの考 え方がある. その一つは Sklash and Farvolden (1979)に代表される土壇水の移動機構に立脚する考 え方であり，他の一つは Jones(1971) に代表される 地層中での卓越流の存在を重要視する考え方である.

Sklash and Farvolden(1979)は, 降雨流出時の地 下水流出機構を次のょうに説明している.「河川近 傍では地下水面が浅いため，降雨によって地表面か ら一様に浸潤が始まると，ぬれ前線はこの付近で最 も早く毛管水縁の上縁に到達する. その結果, 河道 の両側では一時的に地下水面の尾根が形成され，河 道へ向かう地下水面の勾配が急に大きくなり，地下 水流出が增大する」. Ragan(1968)は, 河道近傍の地 下水位の測定から，降雨流出時には河道へ向かう地 下水面の勾配が大きくなる事実を明らかにしている. また, 最近, 佐倉・谷口(1983)は, 比較的浅い地下 水面の存在を想定したカラムによる室内浸透実験の 結果から, ぬれ前線が毛管上昇の上限の位置に到達 すると, 毛管水帯では土壌水の一斉移動が始まり, 地下水面を通過するフラックスが生じることを見い
出しここの現象を毛管水帯における毛管力と重力の 圧力平衡の崩壞に起因するものと規定した上で, Sklash and Farvolden(1979) の仮説を支持する見 解を打ち出している.

また, Hewlett and Hibbert (1967) は, 降雨流 出時の流出の発生機構を説明するにあたり，河道近 傍の飽和帯へ降雨直後に供給される水の大部分は, ピストン流的に土壌の下層から押し出された古い水 によって占められているという考え方を提示し，こ の流れを translatory flow と呼んだ.こ!種の水 移動が土銥中で生じていることは，環境同位体を卜 レーサーにした土㙵水の移動機構に関する研究で確 認されている(例えば，榧根ほか，1980).

降雨流出時の地下水流出に関する以上の考え方は, 流出径路を踏をえた上で，土壇水の移動機構を流出 機構に結びつけている点で画期的である. しかし， 上述した機構によって, 応答の早い多量の地下水流 出が “量的”に説明しうるか否かの検討は未だなさ れておらず，今後の検討課題としての問題点を残し ている.

一方，Jones $(1971,1978)$ は，イギリスの11の地域 においてパイプの空間的分布, パイプ網の発達経路, パイプからの流出量等を明らかにし，降雨に対する 流域の応答として，パイプ流が重要な働きをなして いることを指摘した．また, Newson(1976)はJones と同様に，イギリス，ウェールズの upland での野 外調査に基づいてパイプ流の重要性を見い出し，湿 潤地域でのパイプに関する情報収集の必要性を強調 している.

わが国においては, 太田ほか(1981)や Tsukamoto et al. (1982) が，花崗岩地帯や第三紀～洪積層地帯 および地すべり地までを含んだ地域での表層崩壊と の関連においで7，パイプ流が山腹斜面の流出や崩 壊に強く影響しているであろうことを推論している。 降雨に対する応答の早い多量の地下水流出を “量 的”に説明しうる機構としては，地層中での良好な 
排水システムを考える必要があろう．本研究で明ら かにしたように, 降雨流出時のパイプ流は, 地表流 に匹敵する速い流れを有しており，地層中での良好 な排水システムの一翼を担っているものと考えるこ とができる.すなわち，量的に充分説明しうる排水 機能としてのパイプ流は, 丘陵地源流域における流 出機構を考える上で重要な役割を果たしているもの と考えられる.

しかし，地層中におけるパイプの形成機構，パイ プヘの集水機構や, パイプからの排水機構等, パイ プの水理学的特性や流出特性については, なお不明 な点が多く, これらの点に関する解析は今後に残さ れた重要な研究課題である.

\section{VII まとめ}

本研究では, 多摩丘陵の一角に設定した試験流域 を例に，降雨流出時における流出の主体を明らかに するとともに, その流出機構について考察を行なっ た. 本研究の結果，明らかとなったことがらをまと めると, 以下のようになる.

1. 降雨流出時における流出成分の主体は, 地下 水流出成分である. 本流域においては, 総流出量の 約 $90 \%$ が地下水流出成分によって占められており, 表面流出成分は総流出量のわずか $10 \%$ 程度を占める にすぎない．

2. 降雨に対する応答の早い多量の地下水流出は, ダルシー則に基づく流れでは説明することができな い. 降雨流出時においては, ダルシー流よりはるか に速い卓越流が地層中に存在している.

3. この卓越流は, 地層中に形成されたパイプの 中を流れるパイプ流であり，良好な排水機能として のパイプ流は, 丘陵地源流域における流出機構を考 える上で重要な役割を果たしている.

4. パイプ流の特徴として, pulsating flow 現象 が認められる.

本研究で明らかにされた丘陵地源流域での流出機
構は, 今後, 流域の水循環機構や物質循環機構を考 察する上で, 示唆するところが大きいように思われ る. また, 本研究の結果は, 河川水の水質形成機構, あるいは流域での土壌侵食機構を解明する上で新た な視点を提起することになるものと思われる.

本研究を実施するにあたり，快く施設を提供して下さ った東京農工大学農学部丹下 勲教授に心から御礼申し 上げます. 京都大学防災研究所付属水資源研究センター には多大な援助をしていただいた。ここに深く感謝の意 を表します．また，本論文の草稿を校閲していただいた 筑波大学地球科学系椚根 勇教授ならびに高山茂美教授 に感謝の意を表します。

本研究には昭和56年度文部省科学研究費補助金一般研 究 (B) (研究代表者 : 高山茂美, 課題番号 : 546205)によ る研究費の一部を使用した。記して感謝いたします。な お，本論文の骨子は1982年度春季学術大会で発表したも のである。

（投稿 1983 年 3 月 16 日）

（受理 1983年 7 月 2 日）

注

1) ここでいう流出率とは, 降雨直後の短期間の総 流出量を一雨降水量で除した值であり, 一雨流出 率に相当する.

2）地下水流出とは，「地下水帯を流れる水が地表 へ流出する現象」と定義する.

3）本流域においては, 流出ピーク時におけるポテ ンシャル分布が明らかにされている(田中ほか， 1982). それによれば, 地下水面より上の土壤水 帯での水の流れは，鉛直下方成分が卓越しており， 降雨流出時における土䱋水帯での側方浸透流に起 因する流出成分は，無視することができるものと 判断される.

4) 式 (6)の適用にあたっては, 以下の仮定条件が 満足される必要がありる. (1) $C_{\mathrm{S}}, C_{\mathrm{G}}$ は対象とす る流域内に打いて時空間的に一定である.（2）無 降雨時の河川水のトレーサー濃度は流域の地下水 流出成分のトレーサー濃度を表わしている.

5）地表流発生域の総面積とは, 河道面積, 谷底飽 和面の面積, 水みち流が発生する観測通路面積の 合計を指す.

6）表面流出量 $112 \mathrm{~m}^{3}$ は, $\mathrm{P}_{5}$ に関与する地表流発生 域の最大面積に総降水量をかけて得られた值であ る. Dunne and Black (1970) によれば, この地 表流発生域から流出する水量は, 全降水量の10 $30 \%$ にすぎないとされている。 また, 地表流発生 
域も降雨初期には小さく, 逐次拡大することが確 認されている(田中ほか, 1982), これらのことか ら, 実際に地表流として流出する水量は, 上記の 方法によって求めた值よりは少ないはずである. したがって, 電気伝導度をトレーサーにして分離 された值 $\left(118 \mathrm{~m}^{3}\right)$ は, 表面流出量をやや多めに評 価していることになる.

7) 太田ほか (1981)は, 愛知県西三河の矢作川流域 における花崗岩地帯の崩壊跡地を調査し, 68 カ所 の崩壊跡地のうち, パイプが存在しないものはわ ずか 4 カ所であり, 残りの $94 \%$ の崩壊跡地にはパ イプが存在し，1カ所あたりのパイプの数は平均 3.6 個で，1〜4個のパイプを持つものが全体の 70 \%を占めていると報告している.

\section{文 献}

太田猛彦・塚本良則・野口晴彦(1981)：パイプフロ 一と山崩れについての一考察. 昭和56年度砂防学 会研究発表会概要集, 92 93.

榧根 勇 (1980)：『水文学』大明堂, 272ページ.

榧根，勇・田中 正・嶋田 純 (1980)：環境トリチ ウムで追跡した関東ローム層中の土壌水の移動.

地理評, 53, 225 237.

佐倉保夫・谷口真人 (1983)：土㙵水の移動特性に関 するカラムを用いた降雨浸透実験. 地理評， 56, $81 \sim 93$.

寿円晋吾・原田静男 (1961)：波丘地試験地の地下水 探查. 東京農工大学農学部波丘地研究所報, 第 3 号, 50 56.

田中 正 (1982)：水文学に抢ける同位体利用の研究 動向一一地中水の循環に関する研究を事例として 一. 京都大学防災研究所付属水資源研究センタ 一研究報告, 第 2 号, 3 22.

田中 正・間島政紀・佐藤芳徳 (1980)：蓮沼川およ び西谷田川の流出特性について—ーリチウムと 電気伝導度によるハイドログラフの分離——. 筑 波の環境研究, 第 5 号, A, 20〜25.

田中 正・安原正也・酒井 均 (1982) : 丘陵地源流 域における流出現象と地中水の挙動. 京都大学防 災研究所年報, 第25号, B-2, 181 193.

塚本良則 (1962)：山地流域内に起る水文現象の解析. 東京農工大学農学部演習林報告, 第 6 号, 1 79.

丸井敦尚 (1982 BS)：森林小流域における降雨時の 地下水流出. 筑波大学自然学類昭和 56 年度卒業論 文, 65ページ.

Dinçer, |T., Payne, B. R. and Florkowski, T. (1970) : Snowmelt runoff from measurements of tritium and oxygen-18. Water Resour. Res.,
6, $110 \sim 124$.

Dunne, T. and Black, R.D. (1970) : Partial area contribution to storm runoff, in a small New England watershed. Water Resour. Res., 6, $1296 \sim 1331$.

Freeze, R. A. (1974): Streamflow generation. Rev. Geophys. Space Phys., 12, 627 647.

Fritz, P., Cherry, J. A., Weyer, K. U. and Sklash, M. G. (1976) : Storm runoff analyses using environmental isotopes and major ions. Interpretation of Environmental Isotopes and Hydrochemical Data in Groundwater Hydrology, IAEA, 111 130 .

Herrmann, A. and Stichler, iW. (1980): Groundwater-runoff relationships. Catena, 7, 251 263.

Hewlett, J. D. and Hibbert, A. R. (1967) : Factors affecting the 'response of small watersheds to precipitation in humid areas. Sopper, W. E. and Lull, H. W. eds. : International Symposium on Forest Hydrology. Pergamon Press, Oxford, $275 \sim 290$.

Jones, J. A. A. (1971) : Soil piping and stream channel initiation. Water Resour. Res., 7, 602 $\sim 610$.

Jones, J. A. A. (1978) : Soil pipe networks: distribution and discharge. Cambria, 5, 1 21.

Kirkby, M. J. ed. (1978) : Hillslope hydrology. John Wiley \& Sons, New York, 389 p.

Kobayashi, D. (1981): Separation of runoff components by stream temperature. Verh. Internat. Verein. Limnol., 21, 150 154.

Martinec, J., Siegenthaler, U., Oeschger, H. and Tongiorgi, E. (1974): New insights into the run-off mechanism by environmental isotopes. Isotope Techniques in Groundwater Hydrology 1974, Vol. I, IAEA, 129 143.

Newson, M. (1976) : Soil piping in upland Wales: a call for more information. Cambria, 1, 33 39.

Pilgrim, D. H., Huff, D. D. and Steele, T. D. (1979) : Use of specific conductance and contact time relations for separating flow components in storm runoff. Water Resour. Res., 15, 329 339.

Ragan, R. M. (1968) : An experimental investigation of partial area contributions. Int. Assoc: Sci. Hydrol., Publ. No. 76, 241 249. 
Rodhe, A. (1981): Spring flood, meltwater or groundwater? Nordic Hydrol., 12, 21 30.

Sklash, M. G. and Farvolden, R. N. (1979) : The role of groundwater in storm runoff. J. Hydrol., 43, $45 \sim 65$.

Tanaka, T., Sakai, H. and Yasuhara, M.(1981) : Detection of dynamic responses of subsurface water during a storm event with tensiometer and piezometer nests. ハイドロロジー, No. 11, $1 \sim 7$.

Tanaka, T., Yasuhara, M. and Marui, A. (1982): Pulsating flow phenomenon in soil pipe. Ann. Rep., Inst. Geosci., Univ. of Tsukuba, No. 8, $33 \sim 36$.

Tsukamoto, Y., Ohta, T. and Noguchi, H.(1982) :
Hydrological and geomorphological Studies of dcbris slides on forested hillslopes in Ja pan. Int. Assoc. Hydrol. Sci., Publ., No. 137, 89 98.

Weyman, D. R. (1970) : Throughflow; on hillslopes and its relation to the stream hydrograph. Bull. Int. Assoc. Sci. Hydrol., 15, 25 33.

Weyman, D. R. (1973): Measurements of the downslope flow of water in a soil. J. Hydrol., 20, $267 \sim 288$.

Whipkey, R.Z.(1965): Subsurface storm flow from forested slopes. Bull. Int. Assoc. Sci. Hydrol., 10, $74 \sim 85$.

Whipkey, R. Z. (1969) : Storm runoff from forested catchments by subsurface routes. Int. Assoc. Hydrol. Sci., Publ., No. 85, 773 779.

\section{RUNOFF MECHANISM DURING A STORM EVENT IN THE HEADWATERS OF THE TAMA HILLS}

\section{Tadashi TANAKA*, Masaya YASUHARA** and Atsunao MARUI**}

One of main research subjects in hydrology is to make clear runoff mechanism or mechanism of streamflow generation. A knowledge of this interest is significantly important for better elucidation of the mechanism of the hydrological cycle and of the material cycle in a basin. Because of complexity of basin response to rainfall events, previous studies have tended to analyze the basin response as a black box unit.

In recent years, however, there has been a burst of research activities aiming at obtaining better insight into the mechanism of streamflow generation. Three types of flow have been recognized as main sources of storm runoff, that is saturated overland flow, subsurface stormflow and groundwater flow. It is now commonly accepted that in many drainage basins in humid areas streamflow is controlled dominantly by subsurface flow. However, there remain some major questions concerning causal mechanism of feeding water into stream channels by subsurface flow.

The purpose of this study is to elucidate the main source of storm runoff during a typical storm event and to clarify the runoff mechanism of the specified main component.

The study was conducted in a small forested drainage basin with an area of approximately 2.2 ha in the headwaters of the Tama River system located in the western suburbs of Tokyo (Fig. 1). The basin is located in the Tama Hills which are underlain by the Pliocene Miura group and Pleistocene Narita group. The former is composed of sand, mud

Geographical Review of Japan 57-1 1 19 1984

* Institute of Geoscience, the University of Tsukuba.

** Graduate Student, Institute of Geoscience, the University of Tsukuba. 
and gravel and the latter of gravel and volcanic ash soil, the so-called Kanto Loam. The topography is typical of a dissected diluvial hill having a valley floor slope of about $12 \%$ and steep hillside slopes of about $50 \%$. The upper $2 \mathrm{~m}$ of the soil are broadly classified as clay loam and silty clay (Fig. 2). The vegetation consists of dense deciduous trees approximately $15 \mathrm{~m}$ in height and sparse bamboos $1 \sim 2 \mathrm{~m}$ high with a dense ground cover of ferns and small shrubs.

Within the drainage basin, the valley floor was instrumented for the intensive study (Fig. 3). Precipitation was measured by a tipping bucket recording raingage located in the middle part of the valley floor. Discharge from the basin was continuously recorded at three sites as shown in Fig. 3 using a $90^{\circ} \mathrm{V}$-notch weir and Parshall flumes. To analyze the dynamic response of the basin during a storm event, tensiometer and piezometer nests were utilized. Contributing areas of overland flow to the storm hydrograph were ascertained by field observations during storm events.

Intensive field observations were carried out from July to October 1981. During this period, one of the major storm events occurred on October 22, caused by the Typhoon No. 8124, which provided a total rainfall of $172.5 \mathrm{~mm}$. Discharge began within a few minutes of the onset of rainfall and the peak discharge occurred within 10 minutes of the rainfall peak (Fig. 4).

In the drainage basin, overland flow occurred from restricted areas on the valley floor and no significant overland flow was produced on the steep hillside slopes during storm events. Discharge due to overland flow generating on these restricted areas was too small to account for the total discharge from the basin. This means that the saturated overland flow which has been suggested as a main source of streamflow generation in humid drainage basins on the basis of the variable source area concept does not explain the runoff mechanism of the basin.

On the basis of observations of groundwater discharge around the main weir (Fig. 7) and of the hydrograph separation using specific conductance (Fig. 9), we clarified discharge ratios and flow components between the gaging stations (Fig. 10). As the results of the study, it was confirmed that the main component of the hydrograph was attributed to groundwater flow (Fig. 11) and characteristics of groundwater flow during the storm event were an extreme rapidity of response to the rainfall event and a very large amount of discharge.

To consider the rapid and large discharge of groundwater flow mentioned above, flow net analyses (Fig. 13) and tracer experiments (Fig. 15) were conducted. As the results of flow net analyses, it became clear that actual groundwater discharge was much larger by 2 or 3 orders in magnitude comparing with calculated ones by flow net analyses (Table 2). This means that the groundwater response to rainfall events could not be explained solely by the traditional concept of Darcian flow. On the other hand, tracer experiments, which were conducted to make sure actual velocities of groundwater flow during the storm event, proved that there existed fast flow through natural pipes formed in the soil having a flow velocity like as surface flow.

The results of the study are summarized as follows: 
1. The main source of storm runoff in the basin is groundwater flow. About $90 \%$ of the total discharge are due to groundwater flow and surface runoff component contributes only $10 \%$ of the total discharge.

2. The characteristics of the groundwater response to the rainfall event are an extreme rapidity of response and a very large amount of discharge. These phenomena of groundwater response during the storm event can not be explained by the traditional concept of Darcian flow quantitatively.

3. Large amount of discharge and fast flow of groundwater during the storm event are attributed to pipe flow which flows through natural pipes formed in the soil and flows down over considerable distances at high velocities like as surface flow. It may be recognized that pipe flow as a good drainage system in the soil will play an important role for the runoff mechanism in the headwaters of the hills.

4. Pulsating flow phenomena are observed as a characteristic of pipe flow.

It seems that the results of the study will not only provide additional informations on the runoff mechanism in a basin but will also improve our insight into the role of hydrological system in a basin for considering soil erosion processes and the delivery of pollutants into stream channels. 